\title{
Neilos Kabasilas's Rule of Theology and the Distinction between the Light and Warmth of Fire in Neilos Kabasilas and Gregory Palamas
}

\author{
Dmitry Biriukov
}

National Research University Higher School of Economics, Sociological institute of the Russian Academy of Science

dbirjuk@gmail.com

\begin{abstract}
I review the central propositions of Neilos Kabasilas's Rule of Theology and analyze the pre-history of a particular theme of vital importance for the treatise's wider theological tradition: the distinction between the warmth and light of fire (the sun) in Palamite theology. This analogy meant to clarify the distinction between the divine essence and energies, as well as between the energies themselves.
\end{abstract}

\section{Keywords}

nature - energies - number - unity - difference - uncountability

\section{Introduction}

In this article I review the central propositions of Neilos Kabasilas's Rule of Theology ${ }^{1}$ and analyze the pre-history of a particular theme of vital importance

* This research was carried out with a financial support of the Russian Science Foundation, project 18-18-00134, "The heritage of Byzantine Philosophy in twentieth and twenty-first century Russian and Western European philosophy". I am grateful to Tikhon Pino for improving my English.

1 I use the short title of the treatise given by the publisher (M. Candal, "La 'Regla teológica' de Nilo Cabásilas," Orientalia Christiana Periodica 23 (1957), pp. 237-266). The full title is "A Brief Word against the incorrect understanding of the heretical Akindynists concerning the words of the divine Gregory of Nyssa, that 'There is nothing uncreated except for the divine nature'. 
for the treatise's wider theological tradition: the distinction between the warmth and light of fire (the sun) in Palamite theology. As an analogy meant to clarify the distinction between the divine essence and energies, as well as between the energies themselves, this theme touches upon the central issues of the Palamite controversy.

\section{Summary of the Rule of Theology}

Kabasilas begins his treatise by announcing his intention to differentiate between the meanings of the word "nature" ( $\left.\varphi^{\prime} \sigma \iota \varsigma\right)$, which is used by theologians in different senses. This, according to Neilos, will clarify in what sense the words of Gregory of Nyssa, that there is nothing uncreated except for the divine nature, should be understood, ${ }^{2}$ thus preventing an erroneous conception of the correlation between the divine essence and energies (chapter $1^{3}$ ). As Kabasilas points out, "nature" is used in the sense of "essence" (ov $\sigma i \alpha)$. But in ancient theological language this word could also be used to signify "hypostasis". Furthermore, "nature" could also refer to natural properties, as well as to God himself. It is exactly in this last sense that the word "nature" should be understood in the disputed passage from Gregory of Nyssa (chapter $\left.2^{4}\right)$. But the word "God" embraces everything that relates to God: essence, hypostasis and the natural, uncreated divine energy (chapter $3^{5}$ ).

Those who claim that the word "nature" in this statement of Gregory points only to the common being (essence) of the Trinity, and that the divine energy, which is different from the nature (essence, ov $\sigma^{\prime} \alpha$ ), is therefore something created, are incorrect. For if we follow their logic, the hypostases themselves, being different from essence, are also created, which is absurd and more ungodly than Arianism. But if we acknowledge the difference between the essence (nature) and hypostasis in God, which, as has been shown, does not contradict the statement of Gregory of Nyssa (for in his statement "nature" points to God as

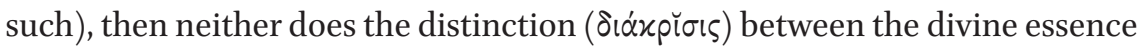
and the divine energy contradict Gregory's statement (chapter $\left.4^{6}\right)$. The difference between the divine essence (nature) and the divine hypostases, and their

Here also: that not only the divine nature is uncreated, but, together with it, its natural properties, too."

2 See: Greg. Nyss. C. Eun. XIIbis: PG 45, 981B; II.213: Gregorii Nysseni Contra Eunomium Libri, Pars Prior, Liber I et II, ed. W. Jaeger, Leiden, 196o, p. 287.14.

3 M. Candal, "La 'Regla teológica' de Nilo Cabásilas", p. 240.

4 Ibid., p. 240-242.

5 Ibid., p. $242-244$.

6 Ibid., p. 244. 
non-identity, can be seen from the fact that the divine essence constitutes the unity of the Trinity, while the divine hypostases are different from one another. Accordingly, that whereby something is one, and that whereby it possesses difference, cannot be identical to each other ( $\operatorname{chapter} 5^{7}$ ). Furthermore, the Horos of the First Ecumenical Council proclaims that the Son of God is from no other essence and hypostasis than the Father, which, as Basil the Great clarifies, attests to the fact that essence and hypostasis are not the same (chapter $6^{8}$ ).

There is also a difference between the divine essence and the natural properties of God. The essence and properties of God relate to each other as unity and plurality; as cause and what is caused; (at this point Neilos, without any explanation, substitutes "energies" for properties) as what is imparticipable and what is participable; as that from which $(\dot{\varepsilon} x)$ the divine hypostases are, and that from which $(\varepsilon x)$ created beings are; as what is unknowable and what is knowable (chapter $7^{9}$ ). Neilos subsequently turns to the question of the distinction between the categories of hypostasis and energy in God. The first is countable (there are three hypostases in God) and definite, whereas the latter

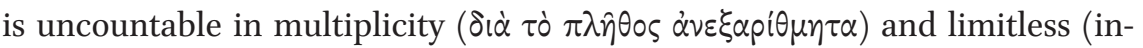

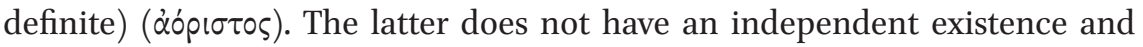
finds its existence in the first. The first is imparticipable, the latter allows participation in itself (chapter $8^{10}$ ). Having put forward, above, the distinction between the divine essence and energies, Neilos counterbalances this statement by noting that, even if the energies in God are different from the essence, they are really divine, i.e., uncreated. According to Neilos, the uncreatedness of the divine energies is attested to by the Fifth and Sixth Ecumenical Councils: the Fifth Council in condemning the Origenist teaching concerning the unlimited power to create, which God has from eternity, and the Sixth Council in its declaration that Christ has two natural energies - one uncreated according to his divinity, and one created according to his humanity (chapter $9^{11}$ ).

Unity and triplicity in God correlate in the following manner: God is one not in number, but in nature. In number he is threefold. The properties of God are said to be manifold. In other words, unity, which is not a number, belongs to the nature of the divinity, ${ }^{12}$ while number, according to Neilos, belongs to the

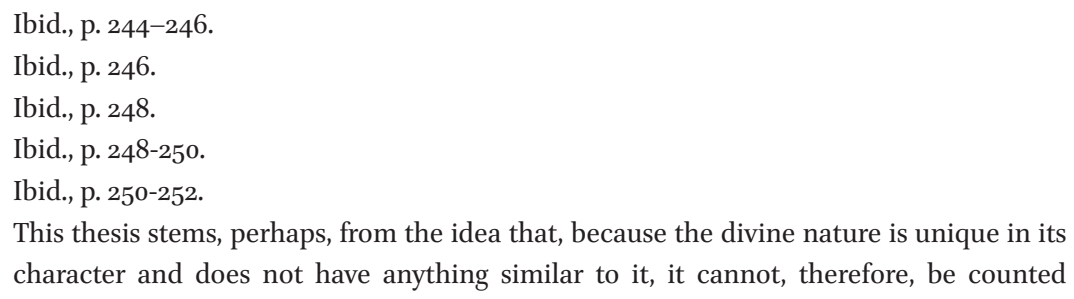


hypostases and natural energies (chapter 10). It should be noted, here, that it remains unclear how this thesis of Neilos can be reconciled with the statement made in chapter 8 , according to which the energies are uncountable (stated in the quotation of Basil of Caesarea ${ }^{13}$ ) and limitless (indefinite). In this way, the text of Neilos either contradicts itself, or, according to Neilos, the energies are called uncountable in the sense that there is no possibility for a human to count them, while they are, in themselves, countable. As for the limitlessness (indefiniteness) of the energies, this could mean that they are either unlimited for the human cognition while having a limit in themselves, or that their limitlessness is an actual infinity. Therefore, since the unity of the divine nature transcends number, and number has to do with the hypostases and natural energies of the Deity, as far as we can understand Neilos's thought, it is impossible to speak about complexity in the Deity, or any differentiation in relation to uncreatedness between the essence of God and his hypostases and energies (chapter $\left.10^{14}\right)$.

For Neilos, we should not think that this doctrine of the divine energies presupposes separation and division, as introducing otherness into God, because it should be admitted that the principle of otherness already has a place in the Deity, due to the hypostases of the Holy Trinity. If the hypostases of the Trinity, being other in relation to one other, do not divide it, neither do the energies

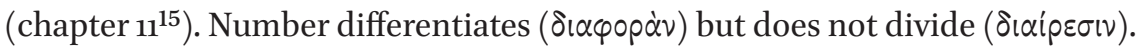
Despite the fact that essence and hypostasis are different, one does not exist without the other. The same is true for essence and energy. They are not identical with one other, and the relation between them is described by Neilos in

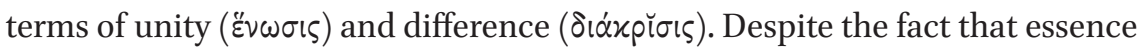
and energies are not identical, the unity between them is real $(\pi \rho \alpha \gamma \mu \breve{\alpha} \tau i x \dot{n})$, while the distinction is described as conceptual ( $\dot{\varepsilon} \pi$ ivoía) (obviously, here he speaks of "unity" in a different sense than when the category was applied to the divine essence above) (chapter $\left.12^{16}\right)$.

Further on, Kabasilas uses the example of light and warmth emanating from fire. These powers, he notes, are not identical, but different, both from each

together with something else. For numerability always implies that what is being counted belong to the same species or genus.

13 See: Bas. Magn. De spiritu sancto 19.49; Basile de Césarée, Sur le Saint-Esprit, ed. B. Pruche (sC, 17bis), Paris, 1968, p. 200.

14 M. Candal, “La 'Regla teológica' de Nilo Cabásilas", p. 252-254.

15 Ibid., p. 254.

16 Ibid., p. 254-256. 
other and from their essence - fire. At the same time, they do not exist separately from one other (chapter $13^{17}$ ). Thus, if even among physical phenomena there are things which differ only in thought (i.e., when things that are not identical differ without separation), then we are able to think of distinction in the same way as concerns the Deity. For, in God, unity prevails over distinction

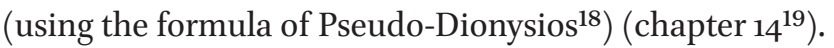

At this point the treatise ends.

\section{The Essence-Energies Distinction in Neilos}

Overall Neilos's treatise has a certain scholastic tone. This consists, in particular, in the successive discussion of differences between essence, hypostases and properties/energies of the Deity. In the beginning of the treatise he discusses the relation between essence and hypostases, then between essence and properties/energies, and then between hypostases and energies.

Terminologically, Neilos distinguishes, on the one hand, between the cate-

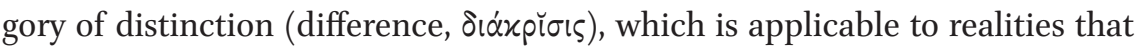
are not identical with one another but coexist indivisibly from each other (this, according to Neilos, is the mode of coexistence of the hypostases, essence and energies in the Deity), and, on the other hand, the category of separation (divi-

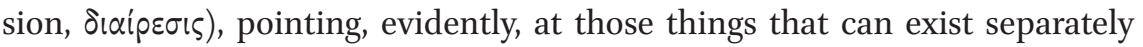
from one another. Additionally, Neilos combines this language with the language of conceptual and real. In order to emphasize the inseparability, even in distinction, of things that are not identical, he speaks of a conceptual distinction and a real unity (both in relation to the distinction of essence and energies, as well as of the energies among themselves). He uses for this purpose the verb $\chi \omega p i \zeta \omega$, pointing to the separate existence of things that exist together, noting that this separation is conceptual in nature (chapters 12, 14).

We can suggest the following diagram to represent the correlation between "essence", "hypostasis" and "energy" ("property"), on the one hand, and, on the other, the other categories utilized by Neilos' in Rule of Theology:

\footnotetext{
$17 \quad$ Ibid., p. 256.

18 Ps.-Dion. De div. nom. 2.11; Pseudo-Dionysius Areopagita, De divinis nominibus, hrsg. v. B.R. Suchla (Patristische Texte und Studien, 33), Berlin, 1990, p. 137.5-6. 


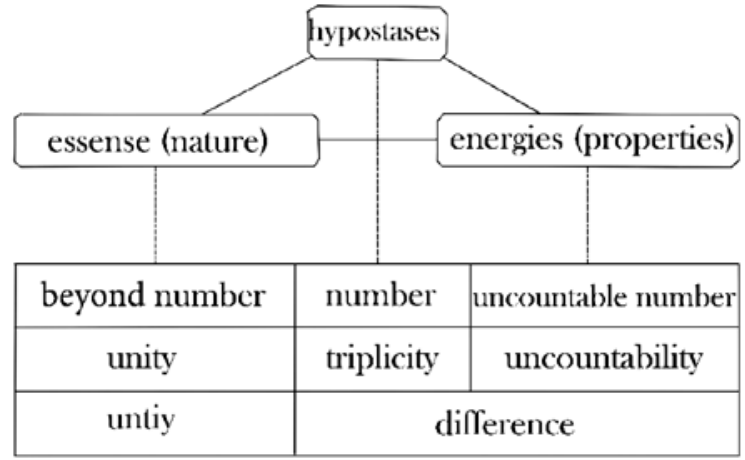

It is to be noted that, in speaking, in the Rule of Theology, of a conceptual distinction between essence and energies in God, Kabasilas follows a trajectory traced in several anti-Palamite writers, as well as in many Palamites. The latter, as suggested by John Demetracopoulos, endeavored in the course of their polemics to soften somewhat the emphasis of Gregory Palamas on the distinction between essence and energies in God, in order to deny the accusation of polytheism from the side of the anti-Palamites ${ }^{20}$. That a conceptual distinction emerges in Neilos Kabasilas is not surprising. Kabasilas, together with another Palamite who taught that the distinction between essence and energies is conceptual, Philotheos Kokkinos, ${ }^{21}$ is the author of the Palamite synodal Tomos of 1351. This synodal decree likewise states that the difference between the essence of God and his energies is conceptual, whereas their unity is real. ${ }^{22}$ As Demetracopoulos notes in his overview of the conceptual distinction and Palamism, the authors in the period of the Palamite controversies who held to such a distinction were often influenced by Latin Scholasticism, known to them through translations of Thomas Aquinas's Summa contra Gentiles, Summa Theologica and De Potentia ${ }^{23}$ undertaken by Demetrios Kydones

20 J. Demetracopoulos, "Palamas Transformed. Palamite Interpretations of the Distinction between God's 'Essence' and 'Energies' in Late Byzantium," in: Greeks, Latins, and Intellectual History 1204-1500, ed. by M. Hinterberger and C. Schabel, Leuven, Paris, Walpole, 2011 (263-372), p. 264.

21 Philotheos Kokkinos. Antirr. 5, PG 151, 878C, 88oD; 8, PG 151, 983AB, 994C.

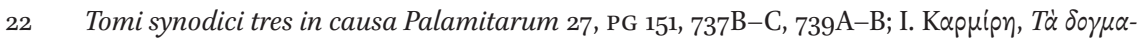

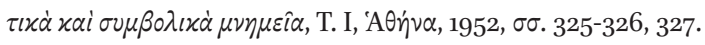

23 I am indebted to Vitaly Ivanov for the following clarification. We should note that in western Scholasticism the topic of the nature of the distinction between the divine essence and essential properties (typically referred to as "attributes" in the West), as well as between the different properties themselves, is underexplored and quite difficult. This is 
due to the fact that the question is interconnected with some of the most important and complex problems of theology and metaphysics. The question itself also underwent significantly changes in the course of Scholastic discussions from the mid-thirteenth to the beginning of the fourteenth centuries, acquiring different significance in different thinkers. The difference between the divine essence and properties was initially discussed only in the context of the divine names (within the specific framework established in the West, by Pseudo-Dionysios, and especially by Augustine) and the problem of their plurality in comparison with the unity of essence. Later, it was often discussed systematically either in the second distinction (on the unity of God) or in the eighth distinction (on the simplicity of God) of the first book of the Commentaries on the Sentences of Peter Lombard. Bonaventure (version of Ordinatio - ca. 1253-1257) mentions the problem of the attributes' plurality only briefly, in the course of his discussion of the divine names and personal properties of the Persons of Trinity (Sent. I d. 22 a. un. q. 4, d. 26 a. un. q. 1; $S$. Bonaventurae, Commentaria in Quatuor libros Sententiarum Magistri Petri Lombardi, Tomus I, In Primum Librum Sententiarum, S. Bonaventurae Opera omnia. Edita studio et cura PP. Collegii a S. Bonaventura, Quaracchi (prope Florentiam), 1882, pp. 397-401, 451454). Thomas Aquinas formulates this problem in terms of the traditional question about the plurality of divine attributes, in his early (version of ordination - ca. 1256-1259) Commentary on the Sentences (I d. 2 q. 1 a. 2; S. Thomas Aquinas, Scriptum super libros Sententiarum magistri Petri Lombardi episcopi Parisiensis, T. 1, Commentum in Primum librum, ed. P. Mandonnet, P. Lethielleux, Parisiis, 1929, pp. 61-63). However, his conclusions here are ambivalent, due perhaps to the lack of any necessity for a specific explication, since the problem was not, at that time, the subject of actual controversy. In all probability, this likewise explains the lack of any explicit discussion of the same theme in his major treatises, which would be translated into Greek. Nevertheless, his Summa contra Gentiles, Summa theologica and De potentia contain a number of places where the distinction of properties is said to exist secundum rationem ("according to reason," i.e. as a logical or rather mental distinction) and to possess unity in re (God). The question is principally, and traditionally, treated by Thomas in the context of the divine names and the arguments that they are not mere synonyms, but have a real foundation in God himself (see esp. De potentia q. 7. a. 6 et 5 (са. 1265-1268 гг.), Summa theologiae I. q. 13 a. 4, also a. 2, 6 et 12; q. 3. a. 6; q. 4 a. 2; S. Thomas Aquinas. Opera omnia iussu impensaque Leonis XIII P.M. edita, Tomus IV, Pars I Summae Theologiae a q. I ad q. XLIX, cura et studio Fratrum Praedicatorum, Romae, 1888, pp. 144-145, also 141-142, 150, 164-165; 45-46; 51-52) (ca. 1265-1267); Summa contra gentiles I. p., c. 31, 35, 36; S. Thomas Aquinas, Opera omnia iussu impensaque Leonis XIII P.M. edita. Tomus XIII. Summa contra Gentiles, Liber I et II, cura et studio Fratrum Praedicatorum, Romae, 1918, p. 95, 109-110 (ca. 1264 г.). Nevertheless, Thomas was compelled to expound upon the distinction between the divine attributes more explicitly and comprehensively in 1265-1267, when he conducted a disputation in Rome, which he would later rework (possibly ca. 1269) and include retroactively, as section 3 of question 1 of distinction 2, in his earlier Commentary on the Sentences. The text, referred to as the "Question on Attributes" in modern research literature, would have the greatest impact upon subsequent tradition, and is considered to be Thomas's final word on the problem. 
Despite the explicit formulation of the problem here, the decision itself would prove unsatisfactory for subsequent theologians. (Briefly speaking, it consisted of the following: although attributes are genuinely in the thing itself, their plurality emanates from the fact that the thing - the divine essence - surpasses our intellect, which attributes simple perfections to God based on our knowledge of creation, see Sent. I d. 2 q. 1 a. 3 co; S. Thomas Aquinas, Scriptum super libros Sententiarum magistri Petri Lombardi episcopi Parisiensis, T. 1, Commentum in Primum librum, ed. P. Mandonnet. Parisiis, 1929, pp. 66-71). Instead, the problems associated with the distinction between the divine essence and attributes, and between the attributes themselves, will became a proper subject of theological discussion only after the death of Aquinas (from approximately the 1270's later on). From the 1270 's to the 1330 's we do not find any theologian of note who devotes special attention to the subject. From the 1270's to the 1330's we do not find any theologian of note who would not devote special attention to the subject." In Scholastic circles, the dominant positions on the distinction between essence and attributes in God were (1) that the distinction is logical/intentional/conceptual (specifying precisely in what kind of intellect, in what manner and on what basis - the positions of the Dominicans, Giles of Rome, Gottfried de Fontaines, and Henry of Ghent); (2) that the distinction is real (from the thing's nature or as a formal non-identity of the attributes, both among themselves and with the essence - the position of Duns Scotus); (3) connotative-conceptual (the position of Aureoli), or purely nominal (the position of Ockham). It would seem, therefore, that the theme of a conceptual distinction between essence and properties in God entered Byzantine theology from these Scholastic discussions in the West, and were borrowed as a commonplace. As of today, there still exists no extensive research, in the form of a published monograph, on the problem of the distinction between essence and attributes in High Scholasticism. Garrett R. Smith, however, of the University of Notre Dame, has recently (November 2013) defended a doctoral dissertation in Medieval Studies on the subject of "The Problem of Divine Attributes from Thomas Aquinas to Duns Scotus". is currently preparing a doctoral dissertation in Medieval Studies on the subject of "The Multiplicity and Distinction of Divine Attributes: Thomas Aquinas to Duns Scotus". For the general theory of the divine attributes in Thomas Aquinas, one may consult the relevant section in the classic book by J.F. Wippel, Metaphysical Themes in Thomas Aquinas, Washington, 1984, pp. 215-241. The historical circumstances surrounding the creation and analysis of Thomas's "Question on Attributes" are described by M. Rubio, Aquinas and Maimonides on the Possibility of the Knowledge of God: an Examination of the 'Quaestio de attributis', Dordrecht, 2007, and a short review of the historical development of this problem can be found in M.J.F.M. Hoenen, Marsilius of Inghen: divine knowledge in late medieval thought, Leiden, 1993, pp. 35-62. The classic study by L. Hödl, "Die philosophische Gotteslehre des Thomas von Aquin op in der Diskussion der Schulen um die Wende des 13. zum 14. Jahrhundert," Rivista di filosofia neo-scolastica 70 (1978), ss. 113-134, is devoted to the history of discussion surrounding the position of Thomas and the problem in general during the last third of the thirteenth century. The types of distinction as they relate to the context of Trinitarian theology (i.e., in the constitution of the Persons), from Thomas Aquinas to Ockham, is 
(a student of Neilos Kabasilas and later author of a treatise directed against Neilos $^{24}$ ) and his brother ${ }^{25-26}$. Neilos Kabasilas unquestionably belongs among

the subject of a lengthy article by M. A. McCord Adams, "The Metaphysics of the Trinity in Some Fourteenth Century Franciscans," Franciscan Studies 66 (2008), pp. 101-168). McCord has also studied Scotus's formal distinction and its critique by Ockham (A. McCord, "Ockham on Identity and Distinction," Franciscan Studies 36 (1976), pp. 5-74). For a historical analysis of Scholastic discussions about the distinction against the background of Trinitarian theology, see I. Iribarren, Durandus of Pourçain: a Dominican theologian in the shadow of Aquinas, Oxford; N. Y., 2005, esp. pp. 29-88, and R. Friedman, Intellectual traditions at the medieval university: the use of philosophical psychology in Trinitarian theology among the Franciscans and Dominicans, 1250-1350. 2 vols., Leiden, 2013. Cf., in this regard the dissertation of H.G. Gelber, Logic and the Trinity: A Clash of Values in Scholastic Thought, 1300-1335, Michigan, 1981 (Ph.D. Thesis, 1974, University of Wisconsin). For contemporary studies of the formal distinction in Duns Scotus and his early followers, see S. Dumont, "Duns Scotus's Parisian Question on the Formal Distinction," Vivarium 43/1 (2005), pp. 7-62, as well as Noone 2009, 127-149. For the later history of Scholastic distinctions, see S. Knebel, "Distinctio rationis ratiocinantis: Die scholastische Unterscheidungslehre vor dem Satz 'A=A," Archiv für Begriffsgeschichte 44 (2002), ss. 145-173; S. Knebel, "What about Aureol? Mastri's Contribution to the Theory of the Distinction of Reason," in: Rem in seipsa cernere. Saggi sul pensiero filosofico di Bartolomeo Mastrius (1602-1673), A cura di M. Forlivesi, Padova, 2006, pp. 415-437.

24 Namely, the treatise Against the Accusations of Neilos Kabasilas against the Chapters of Blessed Thomas on the Procession of the Holy Spirit (unpublished). This work of Kydones is devoted to a polemical treatment of Neilos, On the Procession of the Holy Spirit.

Demetracopoulos writes: "On the one hand, the anti-Palamites liked this idea, because it served their abasement of the ontological status of the divine 'energies'. On the other, the Palamites felt it necessary to soften the harsh Palamite distinction between God's 'essence' and 'energies" as well as between the various 'energies' themselves and adopted the Patristic idea that God is simple ex parte objecti but multiple ex parte subjecti ( $\kappa \propto \tau$ ' $\varepsilon \pi i v o 1 \alpha v$ or $\lambda \hat{o}^{\prime} \omega$, i. e., conceptually or by reason); and they interpreted Palamas' distinctions this way. Further, in so doing, most thinkers on both sides were influenced by Demetrios and Prochoros Cydones' translations of Thomas Aquinas' Summa contra Gentiles, Summa theologiae, and De potentia" (J. Demetracopoulos, "Palamas Transformed", p. 264; cf.: ibid., 370, n. 330). On the Thomist tradition in Byzantium, see: J. Demetracopoulos, "The Influence of Thomas Aquinas on Late Byzantine Philosophical and Theological Thought: À propos of the Thomas de Aquino Byzantinus Project," Bulletin de Philosophie Médiévale 54 (2012), pp. 101-124; M. Plested, "Aquinas in Byzantium," in: The Cambridge Intellectual History of Byzantium, ed. by A. Kaldellis, N. Sinniossoglou, Cambridge, 2017, pp. 542-557 and the bibliography there.

26 It should be noted that the translation of Thomas Aquinas by Demetrios Kydones appeared only after the Synodal Tomos of ${ }^{135}$ (where the topic of conceptual distinction is mentioned) and, apparently, after Neilos wrote the Rule of Theology. Specifically, 
such authors. Being the author of anti-Latin works, Neilos, as Joost van Rossum notes, not only attacks Thomas, but also refers to him several times as an authority ${ }^{27}$. Van Rossum even calls him "a latent 'Palamite Thomist" 28 . In this regard, we can say that the doctrine of a conceptual distinction between the divine essence and energies is in particular the fruit of Western Scholastic influence. Nevertheless, I do not agree with the interpretation of Demetracopoulos that the formulation of conceptual distinction between the divine essence and energies refers to a merely mental distinction. (In this regard, Demetracopoulos claims that Palamas would hardly have approved of the position of Palamites concerning a conceptual distinction ${ }^{29}$ ).

The fact that Neilos speaks of the conceptual character of the distinction between essence and energies, undoubtedly, introduces a terminological ambiguity into the text of his treatise. However it seems to me that in his treatise Neilos teaches that the distinction between essence and energies in God is an actual one, and is only comprehended conceptually. This is attested, in particular, by his oft-stated thesis of the non-identity of essence and energies. The theme of a conceptual distinction appears in his work for polemic reasons, and it does not contradict the traditional Palamite doctrine of an actual, and not merely mental, distinction in God, which Neilos develops in his treatise. In fact, Neilos devoted a special chapter of his treatise (chapter 7 ) to demonstrating the non-identity of the divine essence and energies (properties). This is also evident from the thesis formulated by Kabasilas in the fifth chapter of his treatise: “...God's nature - I mean the common essence of the three hypostases - is not at all identical with the divine hypostasis, or with its natural and essential energy". Here Neilos speaks about the distinction of essence and ener-

Demetrios finished his translation of the Summa theological in 1354. Therefore, if we accept the thesis of a Thomistic influence on Byzantine thinkers as regards a conceptual distinction (which seems justifiable to me), we can suggest that that influence took place thanks to the personal communication of Palamites with Demetrios Kydones, who was versed in Scholastic literature. Otherwise we should accept that Neilos knew Latin and read Thomas himself, which seems unlikely.

J. Van Rossum, Palamism and Church Tradition: Palamism, Its Use of Patristic Tradition, and Its Relationship With Thomistic Thought, N. Y., 1985, (PhD thesis of the Theological Faculty of Fordham University), p. 35. E.g.: Nilus Cab. De Processione Spiritus Sancti; M. Candal, Nilus Cabasilas et theologia S. Thomae de processione Spiritus Sancti: novum e vaticanis codicibus subsidium ad historiam theologiae Byzantinae saeculi XIV plenius elucidandam, (Studi e Testi, 116), Città del Vaticano, 1945, p. 206.21-26.

28 J. Van Rossum, Palamism and Church Tradition, p. 38.

29 It seems that, in this respect, Demetracopoulos follows M. Jugie (Idem, "Palamite, controverse," in: Dictionnaire de Théologie Catholique, T. 11, Paris, 1932 (1777-1818), cols. 1795, 1797). 
gies using the same category of "non-identity" that he uses to speak of the distinction between the divine essence and hypostases. Bearing in mind that, according to Neilos and Orthodox Byzantine theology as a whole, essence and hypostasis differ from each other in reality, we can affirm that in Neilos' description of essence and energies, the notion of non-identity refers precisely to the real distinction between them and cannot be understood as a non-identity only for the mind (as in chapter 12, where he speaks of their conceptual distinction in contrast to their real unity).

In my view, therefore, Neilos's description of a conceptual distinction in the divine essence and energies should be understood in such a way that it points to the presence in the human mind of their actual difference.

\section{Warmth and Light}

The only illustration of conceptual distinction with real unity in Neilos's treatise is the analogy of light and warmth. This image echoes a metaphysics of light whose roots run deep in European philosophy and theology, ${ }^{30}$ but finds a special application in Neilos.

As already mentioned, the distinction between the light and warmth emitted by fire appears in the thirteenth chapter of Neilos's Rule of Theology:

Observe that fire has the power to illuminate, but also the power to warm. It is born upwards. It melts and dries things. And many other things, too, are around fire, differing both from fire's essence and from each other. Though fire warms many things, it illuminates only those possessed of sight. And what that it enlightens, it enlightens instantly, while to those things that it warms it communicates its power in time. If, however, the power to warm were identical to the power to enlighten, then whatever partakes of its warmth would partake of its light as well. Yet, a hand perceives heat but not light. What, then? Is the power to enlighten separate from the power to warm, or can you find warmth separated from the power to enlighten just because these powers differ from one other? In no wise ${ }^{31}$.

$30 \quad$ See, e.g.: W. Beierwaltes, Lux intelligibilis. Untersuchungen zur Lichtmetaphysik der Griechen, Munchen, 1957.

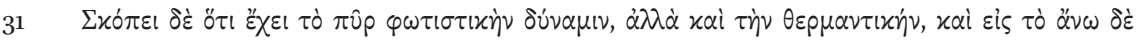

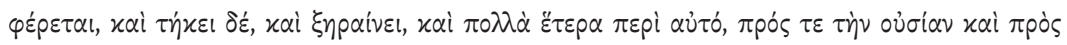

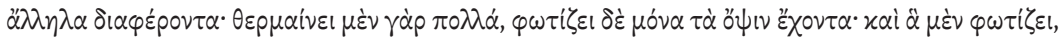


Neilos uses this distinction to illustrate the principle of a distinction without division, which exists, according to the Palamite doctrine that he defends, between the essence, hypostases and energies of the Deity. The immediate meaning of the analogy of light and warmth in the Rule of Theology consists in the illustration of real unity and conceptual distinction between the essence and energies of the Deity, as well as between the energies as such. Relying on this analogy, Neilos speaks about the real unity in the sense of unity of light and warmth in relation to their essence, fire, and about conceptual distinction in the sense of reciprocal distinction between warmth and light, as well between warmth, light, and their common source of existence, fire. Here the distinct contexts are mixed: one, the strictly Palamite context (treated below), another, the context of the Areopagitic corpus (stemming from the Dionysian principle that, in God, unity prevails over distinction), and another, the likely Thomistic influence.

Herebelow I examine the Palamite background of this image in Neilos Kabasilas as an analogy for distinction and unity, specifically, the distinction between the divine energies as such, as well as the distinction and unity of energies and essence in the Deity.

\section{The Analogy of the Sun in Palamas}

We encounter the analogy of light and warmth in various works of Gregory Palamas, where it is used primarily to illustrate the double character of the uncreated divine energies. On the one hand, the energies create and preserve beings, and, on the other, they deify them (effecting theosis), i.e., bring Christians into unity with God and make them Gods by grace. Palamas likens the first aspect of the divine energies to the warmth of the Sun and the second to its light. He speaks about this, in particular, in his 150 Chapters (1349/1350):

Just as the sun, in that without diminution it bestows a measure of warmth and light upon those who participate, possesses these activities as natural and essential energies, so too the divine communications, in that without diminution they inhere in the one who bestows participation,

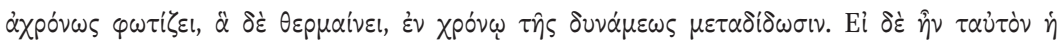

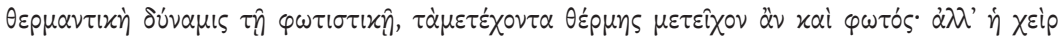

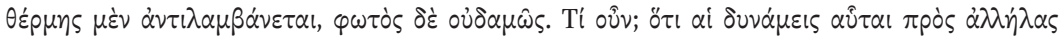

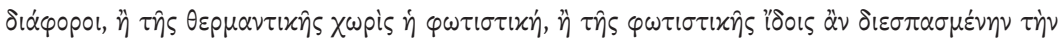

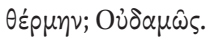


are natural and essential energies of God, and therefore are also uncreated. Even as there is not a trace left of the sun's light when the sun is under the earth and abandons those upon the earth, it is impossible for the eye that once enjoyed this ray not to be mingled with it and through it to be united with what causes the light to pour forth. The warmth of the sun and the effects brought about by it for the generation and growth of sensible creatures when it brings together the manifold differences of the humours and qualities do not abandon these creatures even when there is no contact with the sun through the ray. In the same manner, as in an obscure sensible image, only those who set their path towards the supernatural and most divine Light [i.e. the Light of Thabor] participate purely in divinizing grace and are thereby united with God. All other things are effects of the creative energy, brought forth from nothing by grace as a free gift but not made resplendent by the grace which is a name for the radiance of God. 32

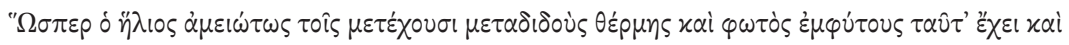

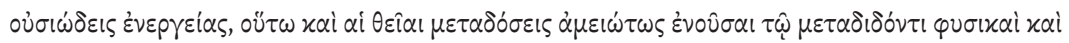

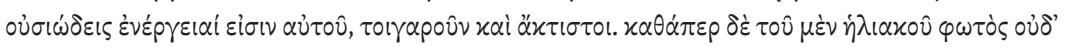

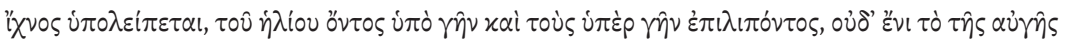

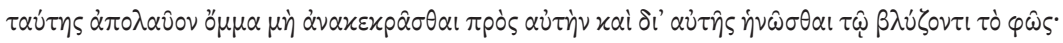

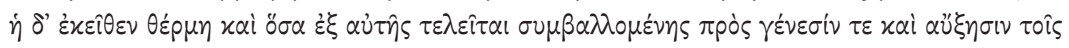

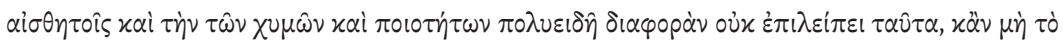

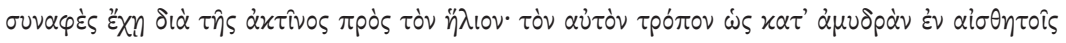

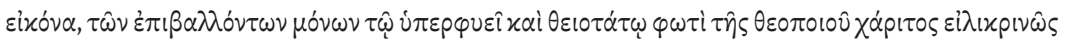

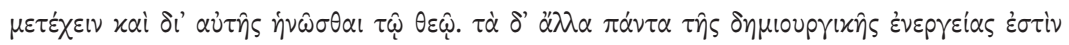

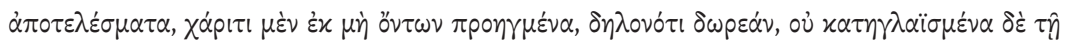

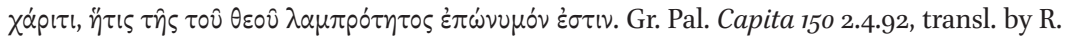
Sinkewicz in: Saint Gregory Palamas, The One Hundred And Fifty Chapters. A Critical Edition, Translation and Study (Studies and Texts 83), Toronto, 1988, pp. 191-193. Cf. Gr. Pal. Capita 150 2.4.94; Saint Gregory Palamas, The One Hundred And Fifty Chapters, pp. 194-195. We encounter the same thought in Gregory's treatise On Divine Union and Distinction (1341-1342): "As the sun, in bestowing warmth and light to its participants without diminution, possesses these things as inherent and essential energies, so also the divine gifts, inhering immanently, without diminution, in the Giver, are his natural and essential energies, and therefore uncreated. <...> And as not even a trace of the sunlight remains when the sun is under the earth and leaves those who are on the earth, and the eye that delights in its radiance is not prevented from mingling with this radiance, and, through it, being united to what emits the light [e.g. the sun]; and as the warmth <emanating > therefrom, and everything that derives from it, contributes to the generation and growth of sensible things, and the pluriform diversity of their humors and qualities, and does not abandon them, even if it is not connected, through the ray, with the sun; the same applies (as a rough image of <what is seen in $>$ sensible things) in the case of those only who strive to 
This analogy with the light and warmth of the sun, as used by Gregory Palamas, serves to clarify a problematic feature of Palamite doctrine that lies at the heart of the polemic between Palamites and their opponents. If the divine energies are uncreated, and through them Christians become uncreated according to grace, then, to the extent that the world is also created by the uncreated divine energies, the danger emerges that the world itself might be uncreated, or possess divine properties ${ }^{33}$. The distinction between the deifying and creative energies, on the one hand, and the comparison, on the other, between the deifying energies (the Light of Thabor) and the light of the sun, and between the creative energies and the sun's warmth (perceptible without the presence of light), therefore suggests a possible clarification of the problem. Though Palamas' does not explicitly formulate the distinction between warmth and light as an illustration of the two distinct types of divine energies, his use of the example implies that the divine energies are different from each other but not separated.

In the Triads (1338-1340), Palamas uses the analogy of light and warmth in a similar context, likening warmth to only one of the natural faculties given by God to creatures, namely the rational and intellective faculty possessed by human beings. (In all, Palamas distinguishes six faculties possessed by creatures, depending on their place in the hierarchy of created being, moving downward in order of commonality: being, life, sense, reason, mind and spirit). ${ }^{34}$

According to Palamas's thinking as laid out in the Triads, the faculty of reason corresponds to the warmth emitted by fire; this faculty is present even when the mind of a person is subject to various passions. Yet the faculty whereby the mind perceives the deifying light of God-intellective sensation, or the eye of the soul, which is activated when the mind is liberated from the pas-

participate fully in the supernatural and most divine light of deifying grace, and to be united with God through it. But everything else is the product of the creative energy, by grace having been brought forward out of non-being, i.e., as a gift, but not irradiated by

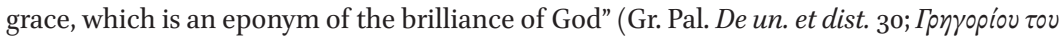

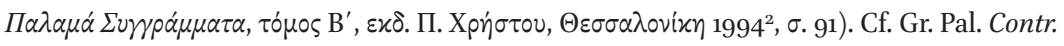

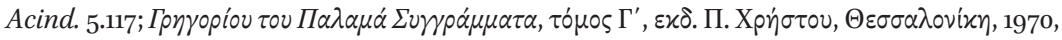
б. 376 .

Concerning an objection on the part of Nikephoros Gregoras, see Phakrasis, Disp. 8; M. Candal, "Fuentes Palamíticas. Diálogo de Jorge Facrasí sobre el contradictorio de Pálamas con Nicéforo Grégoras," Orientalia Christiana Periodica 16 (1950) (303-357), p. 336.

I treat this topic and its context in greater details and with additional references to related loci in Palamas's works, in: D. Biriukov, "Hierarchies of Beings in the Patristic Thought. Maximus the Confessor, John of Damascus and the Palamite literature," Scrinium. Journal of Patrology, Critical Hagiography, and Ecclesiastical History, Ed. by B. Lourié, N. Seleznyov 10 (2014), pp. 281-304. 
sions, corresponds to the light emitted by fire. Just as sensory vision cannot function without external illumination, and just as, in seeing illuminated objects, it becomes light itself, and in this way emerges together with the light, so, in the same way, intellective sensation is activated by the descent of divine Light to the man who is able to receive it. Uniting with this Light, the mind itself becomes as light and sees in itself, and in everything, this diffused light:

As fire, when it is covered by an opaque substance, can heat it but not illumine it, so, in the same way, the mind, when it is covered by a dark veil of evil passions, can generate knowledge, but not light. For the mind is not only the light contemplated by mind, even if this is the highest of the things that are visible in this way, but it is also the thing that contemplates light, being like the eye of the soul. For [as Basil the Great] says, "the mind that adheres to soul is its sight" 35 . Thus, as sensory vision cannot act without light shining on it from without, so the mind, as the one that possesses intellective sensation, could not see and act in itself if the divine light does not shine upon it. As vision, when it is active, itself becomes light, and emerges simultaneously with the light and sees first of all this very light, diffused around all visible things, so, in the same way, the mind, when it attains the fullness of intellective sensation, is itself wholly as light, and is together with the light, and by means of the light clearly sees light, not only beyond bodily sensations but beyond anything cognizable, and all beings in general $<\ldots .>$ Those who have not experienced the things of God, or beheld them, and who do not believe at all that God can be seen as a light beyond light, but instead think that he is contemplated only in speculative reasoning, are like the blind, who, perceiving only the warmth of the sun, do not believe that, for those with sight, the sun also shines. If the blind attempted to persuade the sighted that the sun, which is the brightest of all sensible things, is not light, they would become a laughingstock to all those with sensory sight. ${ }^{36}$

Bas. Magn. Const. mon., PG 31, 1340A.

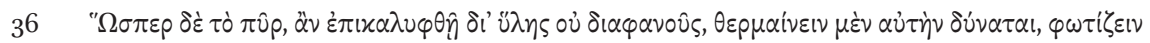

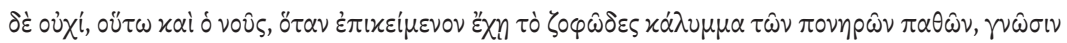

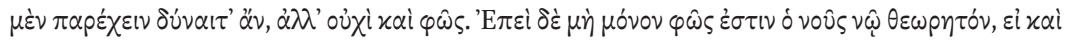

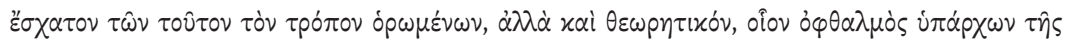

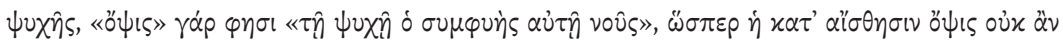

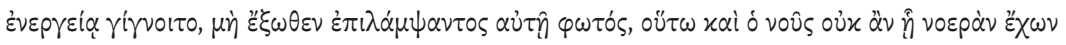

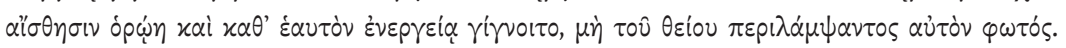

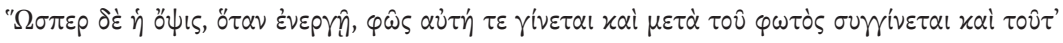

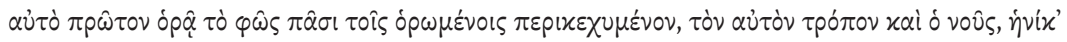

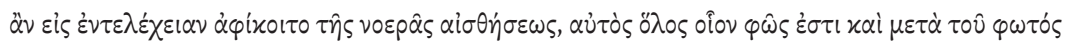


Returning to Neilos, I would note that the context of the image of a fire's light and warmth in the thirteenth chapter of the Rule of Theology points to the fact that this image is used to illustrate not only the difference between essence and energies (a logical corollary of the discussion pursued at the end of chapter 12) but also the distinction between the various divine energies themselves. Neilos distinguishes between the essence of fire and that which is around it, which is different from the essence as well as from each other, and then proceeds to identify the various properties and powers of fire (corresponding, within the framework of his analogy, to the divine energies), including light and warmth. The emphasis, for Neilos, is on the distinction without division that obtains between these powers. They are non-identical with one other, but exist inseparably from each other. If we bear in mind that the analogy of light and warmth was used by Gregory Palamas to distinguish two kinds of divine energies, we can conclude that warmth, in the analogy of Neilos as in Palamas, corresponds to the creative energies of God, whereas light corresponds to the deifying energies. Implicit in Neilos's account, then, is the same problem encountered earlier in Gregory Palamas: a distinction (without division) between the creative and deifying energies of God. In this way, the category of distinction, initially used by Neilos in relation to the essence and hypostases of God, and subsequently in relation to the divine essence and energies (properties), is now extended to the energies themselves.

\section{Temporality}

An important nuance in Neilos' doctrine of the distinction and unity of the divine energies is the theme of timelessness/temporality, which emerges in Neilos's discussion of warmth and light. This theme, as presented by Neilos, is also contextualized by the writings of Palamas.

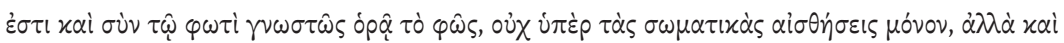

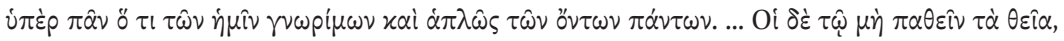

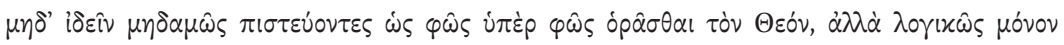

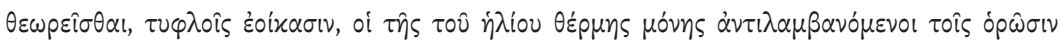

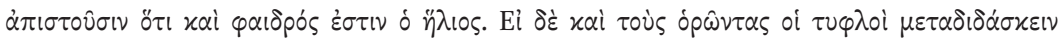

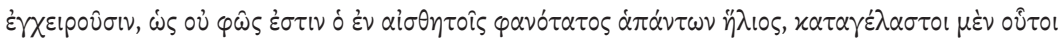

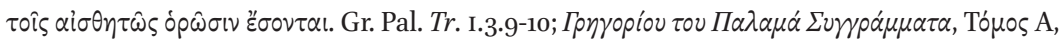

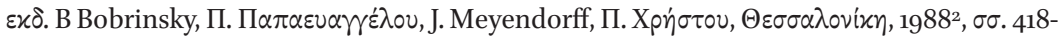

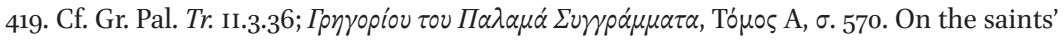

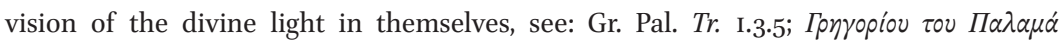

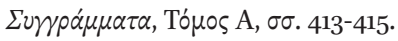


In the thirteenth chapter of the Rule of Theology Neilos states that the activity of warming is a function of time, while light illumines those who are able to

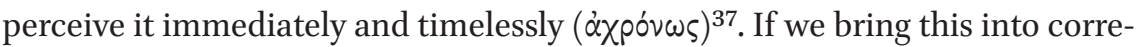
lation with the fact that Gregory Palamas uses sensible light as an analogue for the divine light of Tabor, we can see in Neilos an allusion to the concept of light in Palamas. Indeed, for Palamas, when the sensible light appears, it simultaneously activates the vision of those who have the faculty of sight (Gr. Pal. Tr. I.3.9, see above). As well as the archetype of sensible light, the Light of Tabor (the most important aspect of the concept of light in Palamas) is understood to be timeless ( $\alpha$ xpovov) ${ }^{38}$, and is perceived by intellective sensation, or the eye of the soul. Like Palamas, Neilos Kabasilas also describes a case in which something that is unable to perceive the light emitted by fire (specifically, a hand) perceives only the fire's warmth. In this way he illustrates the distinction (without division) between the two most important forces of fire: its ability to shine and its ability to warm, which do not exist separately from one another. Palamas mentions the same situation when he describes persons who are unable to perceive the uncreated divine light and therefore deny it, insisting that knowledge of God is attained only through the rational faculty. Palamas likens these people to blind men, ${ }^{39}$ who perceive only the warmth of light and do not believe that the sun is also the source of light (Gr. Pal. Tr. I.3.10, see above).

The distinction between the temporal character of the diffusion of warmth and the timeless character of the diffusion and perception of light, which Neilos Kabasilas formulates in the same, thirteenth chapter of his Rule, is implicitly contained in the thought of Gregory Palamas. Using the example of a distinction between light and warmth, he illustrates the distinction between the faculty of reason and cognition, on the one hand (corresponding within the framework of this metaphor to warmth), and intellective sensation (corresponding to light), on the other. As far as we are able to discern, Palamas's understanding of thinking and cognition, as distinct from the activity of the intellective sensation, consists in the following. The first is possible only in time ${ }^{40}$ while the latter, if we take into account the atemporal character of the Light of Tabor, is an atemporal event. We can therefore suggest that the

\footnotetext{
37 M. Candal, "La 'Regla teológica' de Nilo Cabásilas", p. 256.7.

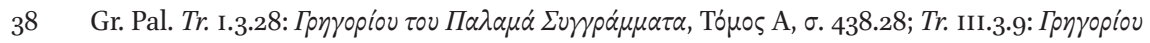

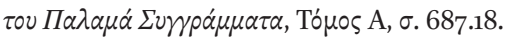

39 It is evident that, here, Gregory Palamas is referring to his opponents, the anti-Palamites (specifically to Barlaam of Calabria, with whom he polemicized in the Triads).

40 Gr. Pal. Capita 150 I.7.35-36; Saint Gregory Palamas, The One Hundred And Fifty Chapters, pp. 120-122.
} 
reference to a temporal continuum, explicitly expressed by Neilos in discussing the mechanics of the diffusion of warmth, is also present in Gregory Palamas, in his correlation of human reason and cognition with the warmth of a fire. At the same time, we can further suggest that the reference to timelessness, explicitly formulated by Neilos in his statement about a sighted person's perception of light, is also present in Palamas, in his correlation of intellective sensation with the light of the sun (fire).

These connections between the thirteenth chapter of Neilos's Rule and the aforementioned writings of Palamas point to Neilos's dependence upon the problems connected to the distinction between the divine energies in Gregory Palamas. Yet the analogy of light and warmth in Palamas also presents another dimension, which allows us to clarify the relationship between energies and essence in the Deity, namely their distinction and unity.

\section{Distinction and Unity}

In the Triads, Palamas has occasion to speak of the warmth and light emanating from fire (without emphasizing the difference between these forces) in the same way developed by Neilos Kabasilas, namely in the context of a distinction without division. Gregory does so, specifically, in connection with his understanding of the Light of Tabor (the divine energy) as a natural symbol of the divine nature. Based on the writings of Maximos the Confessor, Palamas distinguishes between natural and non-natural symbols. Symbols are natural when the object that symbolizes originates from the thing symbolized. They are non-natural when the symbol and the thing symbolized relate to each other in an external manner. As examples of natural symbols, Palamas mentions the warmth of fire and the light of the sun. He develops this theme to illustrate, on the one hand, that the light of Tabor (the divine energy) is innate to the divine essence. But he also seeks to illustrate the case of realities that are naturally bound up with one another, wherein one is the cause of the other's existence (Palamas speaks of such realities in terms of natural symbols). In such cases cognition and participation occur at the level of the symbol, and not what is symbolized. This means that cognition of and participation in fire, and the sun, occur not at the level of the objects themselves, but at the level of their warmth and light. In the same way the Deity is known and participated in through the divine energies (the light of Tabor), remaining unknowable and imparticipable in its interiority. ${ }^{41}$ 
This connection between the analogy of warmth and light and the theme of natural symbolism in Gregory Palamas allows us to further elucidate an aspect of the analogy as it occurs in Neilos Kabasilas and which is not expressed as explicitly as it could be. We refer here specifically to the way in which natural symbolism is used by Palamas to express not only the distinction between essence and energies (the level of their difference), but also the presence of the essence in the energies (as in the case of fire, which, according to Kabasilas, inhere in warmth and light), which thereby shows them to be uncreated (the level of unity of the essence and the energies). Accordingly, if we take into account the connotations of warmth and light in Gregory's discourse of natural symbolism, we may state that when Neilos Kabasilas, in discussing the warmth and light of fire in chapter thirteen of his Rule of Theology, implicitly invokes the thesis of chapter nine: the uncreatedness of the divine energies stemming from their natural inherence in the Deity.

Here we should note that the theme of natural symbolism refers not only to the level of unity, but to distinction as well, which is real and grasped by thought and yet not merely mental. For it is in this way that that which symbolizes and that which is symbolized is used in the Palamite tradition to refer to the difference between essence and energies in the Deity. Behind Neilos Kabasilas's description, then, of a conceptual distinction between the divine essence and energies, as well as between the various energies themselves, we see a deeper context connected to Palamas's doctrine of natural symbols.

\section{Conclusion}

The observations outlined in this paper bear witness to the fact that Neilos's use of the image of a fire's warmth and light conveys not only the immediate sense of a distinction without division, but a whole range of imbued meanings and connotations, injected into the analogy by Gregory Palamas in the course of his writings. Explicating these connections, and the deeper subtext of the analogy, allows us to enter more deeply into the meaning of Neilos's text and to better understand the dynamics of this rich image as it appears in the Rule of Theology. 